\title{
ANALISIS PERAN KELEMBAGAAN LOKAL TERHADAP KONDISI EKONOMI MASYARAKAT PEDESAAN MULTIETNIS DI KECAMATAN BONEGUNU KABUPATEN BUTON UTARA
}

\author{
(Local Institutional Role Analysis Of Economic Condition Of Multiethnic Rural \\ Community In Bonegunu District North Buton Regency)
}

\author{
Zessy Ardinal Barlan ${ }^{1)}$
}

\author{
${ }^{1)}$ Departemen Sains Komunikasi dan Pengembangan Masyarakat, Fakultas Ekologi Manusia, \\ Institut Pertanian Bogor, Dramaga Bogor 16680, Indonesia \\ E-mail: zessyardinalbarlan@apps.ipb.ac.id
}

\begin{abstract}
Indonesia is famous for its diverse ethnicity. This ethnic diversity affects the diversity of community values in building interactions. People build interaction one of them to meet the needs of his life, so that people in general use institutional as a container to interact with each other in accordance with prevailing norms and values. The most primary needs of the community is to meet the needs of food and board clothing. Institutions that meet this need are economic institutions. The formulation of the problem of this research are (1) How is local institution developing in multiethnic rural community in Bonegunu Sub-district of North Buton Regency? (2) What is the economic condition of multiethnic rural community in Bonegunu Sub-district of North Buton Regency? and (3) How is the Institutional Role local in improving the economy of multiethnic rural communities in Bonegunu Sub-district of North Buton Regency? This research is a qualitative research with purposive informant selection technique. The result of this research is the local institution that developed in Bonegunu Sub-district that is Customary Institution. Bonegunu Sub-district generally has high potential of rice fields. However, this potential has not been utilized properly due to the absence of adequate irrigation channels. Therefore, people use social capital and kinship relationships that exist between them. In addition, the consensus is built between ethnic groups also make multiethnic communities can together to solve economic problems without losing their identity
\end{abstract}

Keywords: Ethnicity, Poverty, Social Capital

\begin{abstract}
ABSTRAK
Indonesia terkenal dengan keragaman etnisnya. Keragaman etnis ini mempengaruhi keragaman nilai-nilai masyarakat dalam membangun interaksi. Orang membangun interaksi salah satunya untuk memenuhi kebutuhan hidupnya, sehingga orang pada umumnya menggunakan kelembagaan sebagai wadah untuk berinteraksi satu sama lain sesuai dengan norma dan nilai yang berlaku. Kebutuhan utama masyarakat adalah untuk memenuhi kebutuhan makanan, pakaian, dan papan. Lembaga yang memenuhi kebutuhan ini adalah lembaga ekonomi. Kabupaten Buton Utara merupakan kabupaten baru yang mekar dari kabupaten induknya yaitu kabupaten buton pada tahun 2007. Adanya kebijakan transmigrasi di Kabupaten Buton, membuat kabupaten ini memiliki masyarakat yang sangat heterogen. Terkait dengan keberagaman masyarakat Buton Utara akibat adanya kebijakan transmigrasi maka menarik untuk melihat bagaimana peran kelembagaan dalam meningkatkan kesejahteraan masyarakat? Merujuk hal tersebut, rumusan masalah dalam penelitian ini adalah (1) Bagaimana institusi lokal berkembang di masyarakat pedesaan multietnis di Bonegunu Kecamatan Kabupaten Buton Utara?, (2) Bagaimana kondisi ekonomi masyarakat pedesaan multietnis di Kecamatan Bonegunu Kabupaten Buton Utara?, dan (3) Bagaimana Peran Kelembagaan dalam meningkatkan ekonomi masyarakat pedesaan multietnis di Bonegunu Kecamatan Kabupaten Buton Utara ?. Penelitian ini merupakan penelitian kualitatif dengan teknik pemilihan informan purposive. Hasil dari penelitian ini adalah institusi lokal yang berkembang di Kecamatan Bonegunu yang merupakan Lembaga Adat. Kecamatan Bonegunu umumnya memiliki potensi sawah yang tinggi. Namun, potensi ini belum dimanfaatkan dengan baik karena tidak adanya saluran irigasi yang memadai. Karena itu, orang menggunakan modal sosial dan hubungan kekeluargaan yang ada di antara mereka. Selain itu, konsensus yang dibangun antar kelompok etnis juga membuat komunitas multietnis dapat bersama-sama memecahkan masalah ekonomi tanpa kehilangan identitasnya.
\end{abstract}

Kata Kunci: Etnisitas, Kemiskinan, Modal Sosial 


\section{PENDAHULUAN}

Manusia dalam memenuhi kebutuhannya tentu tidak dapat hidup sendiri, maka dari itu secara alami manusia akan hidup bermasyarakat dan membentuk kelompok kelompok agar dapat memenuhi kebutuhan hidupnya. Manusia secara berkelompok akan membangun interaksi diantara mereka untuk mencapai tujuan mereka, namun tidak hanya interaksi yang terbangun, melainkan kelembagaan juga akan mulai terbangun.

Istilah kelembagaan sering juga dikenal dengan istilah pranata sosial. Koentjaraningrat (1964) dalam Nasdian (2015) mengatakan pranata sosial adalah "suatu sistem tata kelakuan dan hubungan yang berpusat kepada aktivitas-aktivitas untuk memenuhi kompleks-kompleks kebutuhan khusus dalam kehidupan masyarakat". Mengacu pada hal ini, tentunya interaksi masyarakat dalam kelompok-kelompok tersebut sangat dipengaruhi oleh kelembagaan yang terbangun diantara mereka. Selain itu kelembagaan menurut Nasdian (2015) adalah "himpunan norma-norma segala tingkatan yang berkisar pada suatu kebutuhan pokok di dalam kehidupan masyarakat". Normanorma yang terbangun tentunya dipengaruhi oleh nilai-nilai yang menginternalisasi di masyarakat. Maka dari itu dapat disimpulkan bahwa berjalannya kelompok tersebut tentunya dipengaruhi oleh nilai nilai yang terinternalisasi di masyarakat.

Indonesia terkenal dengan etnisnya yang beragam. Tentunya hal ini dapat menjadi kelebihan sekaligus kelemahan bagi Indonesia. Keberagaman etnis dapat menjadi keuntungan karena nilai-nilai etnisitas tidak hanya mengatur interaksi tetapi juga cara masyarakat memandang sumberdaya disekitar mereka dalam rangka pemenuhan kebutuhan hidupnya. Nilai-nilai etnisitas tentunya telah disosialisasikan secara turun temurun dalam waktu yang lama, sehingga kelembagaan yang didasari pada nilai-nilai etnisitas cenderung lebih bertahan lama dan kuat. Walaupun resiko dari tantangan global yang dihadapi saat ini adalah hilangnya kelembagaan yang didasari pada nilai-nilai etnisitas dikarenakan masyarakat tidak lagi mempercayai nilai-nilai lokal dan mulai tersentuh dengan nilainilai universal.
Kebutuhan masyarakat yang paling primer adalah memenuhi kebutuhan sandang pangan dan papan. Kelembagaan yang memenuhi kebutuhan ini adalah kelembagaan ekonomi. Kelembagaan ekonomi berfungsi menurut Koentjaraningrat (1979) dalam Nasdian (2015) yaitu untuk memenuhi pencaharian hidup, memproduksi, menimbun, mendistribusikan harta benda. Mengacu pada hal tersebut yang dimaksud dengan kelembagaan ekonomi tidak hanya untuk bertahan hidup saja tetapi juga untuk meningkatkan kesejahteraan masyarakat.

Kabupaten Buton Utara merupakan kabupaten baru yang mekar dari kabupaten induknya yaitu kabupaten Buton pada tahun 2007. Luasnya lahan kabupaten Buton Utara yang belum digarap membuat pemerintah mengeluarkan kebijakan transmigrasi dari Jawa dan Bali masuk ke Buton Utara. Terkait dengan keberagaman masyarakat Buton Utara akibat adanya kebijakan transmigrasi maka menarik untuk melihat bagaimana peran kelembagaan dalam meningkatkan kesejahteraan masyarakat? Merujuk hal tersebut, rumusan masalah penelitian ini sebagai berikut:

1. Bagaimana kelembagaan lokal yang berkembang pada masyarakat pedesaan multietnis di Kecamatan Bonegunu Kabupaten Buton Utara?

2. Bagaimana kondisi ekonomi masyarakat pedesaan multietnis di Kecamatan Bonegunu Kabupaten Buton Utara?

3. Bagaimana Peran kelembagaan lokal dalam meningkatkan ekonomi masyarakat pedesaan multietnis di Kecamatan Bonegunu Kabupaten Buton Utara?

\section{PENDEKATAN TEORITIS}

\section{Kelembagaan dan Etnisitas}

Nasdian (2015) menyebutkan bahwa terdapat dua perspektif tentang kelembagaan sosial. Pertama, perspektif yang memandang kelembagaan sebagai kompleks peraturan dan peranan sosial secara abstrak, dan memandang asosiasi-asosiasi sebagai bentuk-bentuk organisasi yang kongkrit. Kedua, suatu perspektif yang memandang baik kelembagaan maupun asosiasi sebagai bentuk organisasi sosial, yakni sebagai kelompokkelompok, hanya kelembagaan bersifat lebih universal dan penting. Sedangkan asosiasi 
bersifat kurang penting dan bertujuan lebih spesifik. Misalnya, keluarga dan negara adalah kelembagaan, sedangkan klub-klub sepakbola dan serikat-serikat buruh adalah asosiasi.

Karena kelembagaan sosial bertujuan memenuhi kebutuhan pokok manusia, maka ia dapat dikategorikan berdasarkan jenis-jenis kebutuhan pokok tersebut. Koentjaraningrat (1979) dalam Nasdian (2015) mengkategorikannya ke dalam delapan golongan, sebagai berikut :

1. Kelembagaan Kekerabatan/Domestik: memenuhi kebutuhan kehidupan kekerabatan. Contoh: pelamaran, poligami, perceraian, dan lain-lain.

2. Kelembagaan Ekonomi: memenuhi pencaharian hidup, memproduksi, menimbun, mendistribusikan harta benda. Contoh: pertanian, peternakan, industri, koperasi, perdagangan, sambatan, dan lain-lain.

3. Kelembagaan Pendidikan: memenuhi kebutuhan penerangan dan pendidikan manusia agar menjadi anggota masyarakat yang berguna. Contoh: pendidikan dasar/ menengah/tinggi, pers, dan lain-lain.

4. Kelembagaan IImiah: memenuhi kebutuhan ilmiah manusia dan menyelami alam semesta. Contoh: pendidikan ilmiah, penelitian, metode ilmiah, dan lain-lain.

5. Kelembagaan Estetika dan Rekreasi: kebutuhan manusia untuk menyatakan rasa keindahannya dan rekreasi. Contoh: seni rupa, seni suara, seni gerak, kesusasteraan, dan lain-lain.

6. Kelembagaan Keagamaan: memenuhi kebutuhan manusia untuk berhubungan dengan Tuhan atau alam gaib. Contoh: upacara, selamatan, pantangan, dan lain-lain.

7. Kelembagaan Politik: memenuhi kebutuhan manusia untuk mengatur kehidupan kelompok secara besar-besaran atau kehidupan bernegara. Contoh: pemerintahan, kepartaian, demokrasi, kepolisian, kehakiman, dan lain-lain.

8. Kelembagaan Somatik: memenuhi kebutuhan jasmaniah manusia. Contoh: pemeliharaan kesehatan, pemeliharaan kecantikan, dan lain-lain.

Secara etimologis, kata etnis berasal dari bahasa Yunani yaitu "Etnichos" yang digunakan untuk menerangkan keberadaan sekelompok penyembah berhala. Dalam perkembangannya kemudian istilah etnis mengacu pada kelompok yang diasumsikan memiliki sikap fanatik terhadap ideologinya. Sedangkan dalam ilmu sosial kata etnis itu sendiri mengacu pada sekelompok penduduk yang mempunyai kesamaan sifat-sifat kebudayaan, misalnya bahasa, adat istiadat, prilaku budaya karakteristik budaya, serta sejarah (Ali Liliweri, W.S.:2001, Chris Barker, 2004 dalam Hermansyah 2008).

Frederickson (2003) mengatakan bahwa etnik dapat dilacak melalui tanda-tanda atau petanda yang dimiliki oleh individu atau kelompokkelompok sosial, seperti bahasa, agama, kebiasaan, dan ciri fisik yang dibawa sejak lahir. Barth (1988) menambahkan bahwa kelompok etnik tergantung pada kemampuan seseorang atau kelompok ini untuk memperlihatkan sifat budaya kelompok tersebut. Selain itu Barth menambahkan bahwa budaya yang tampak menunjukkan adanya

\section{PENDEKATAN LAPANG}

Penelitian ini dilakukan di Kecamatan Bonegunu Kabupaten Buton Utara. Pemilihan lokasi didasari atas karakteristik masyarakat yang multietnis di Kecamatan Bonegunu akibat adanya kebijakan transmigrasi yang diberlakukan oleh pemerintah Indonesia pada tahun 1993. Penelitian ini merupakan penelitian kualitatif dimana pemilihan informan dilakukan secara purposive. Pemilihan informan dilakukan secara purposive dengan kriteria bahwa informan merupakan pihak yang mengetahui dengan baik mengenai kelembagaan lokal di kecamatan Bonegunu. Informan penelitian ini diantaranya yaitu camat, ketua kelompok tani, ketua kelompok etnis, ketua lembaga adat, dan stakeholder lainnya yang dianggap memiliki pengetahuan terkait dengan topik yang diteliti. Tahapan penelitian ini meliputi tahap pengumpulan data sekunder, observasi dan analisis lapang, serta penulisan. Adapun lama penelitian ini yaitu dari bulan Desember 2016 hingga Februari 2017. 


\section{PEMBAHASAN}

\section{Kelembagaan Lokal Masyarakat Pedesaan Multietnis di Kecamatan Bonegunu Kabupaten Buton Utara}

Kabupaten Buton Utara secara administrasi merupakan kabupaten yang terletak di Provinsi Sulawesi Tenggara, tepatnya di Pulau Buton. Kabupaten Buton Utara merupakan pemekaran dari kabupaten induknya yakni Kabupaten Muna pada tahun 2007. Pemekaran ini didasarkan pada Undang-Undang Nomor 14 Tahun 2007 tanggal 2 Januari 2007 Tentang Pembentukan Kabupaten Buton Utara di Provinsi Sulawesi Tenggara yang meliputi enam kecamatan, yaitu Kecamatan Bonegunu, Kecamatan Kambowa, Kecamatan Wakorumba, Kecamatan Kulisusu, Kecamatan Kulisusu Barat dan Kecamatan Kulisusu Utara. Adapun pada penelitian ini lebih dikhususkan pada Kecamatan Bonegunu.

Komposisi penduduk di Kecamatan Bonegunu terdiri dari penduduk asli serta penduduk transmigran dari Jawa dan Bali. Tentunya komposisi penduduk ini juga mempengaruhi kelembagaan yang berkembang di Bonegunu. Salah satu kelembagaan yang berkembang adalah kelembagaan adat. Kelembagaan adat ini muncul dan lahir diwarnai oleh nilai-nilai agama sehingga kedepannya penyebutan kelembagaan dalam penelitian ini disebut sebagai kelembagaan adat, walaupun perbedaan kelembagaan adat ini bukan didasari hanya pada perbedaan etnis tetapi juga perbedaan agama yang dimiliki oleh masyarakatnya. Kelembagaan adat di Kecamatan Bonegunu merupakan kelembagaan yang dibangun dengan tujuan melestarikan adat istiadat dan juga untuk memenuhi kebutuhan dalam aspek religius masyarakat. Hal ini dikarenakan kebutuhan religius dan pelestarian budaya merupakan hal yang hampir sulit dipisahkan pada masyarakat di Kecamatan Bonegunu. Terkait pertanian, kelembagaan adat ini biasanya berperan dalam mengadakan upacara/perayaan saat panen. Bagi umat Hindu yang pada umumnya didominasi oleh Etnis Bali biasanya melakukan upacara khusus di pura saat panen raya sedangkan bagi umat Islam biasanya mengadakan acara makan bersama di balai desa. Kelembagaan adat ini sebenarnya terinspirasi oleh sistem subak dibali, sistem subak pada dasarnya juga merupakan kelembagaan yang mengatur pengelolaan usaha tani secara keseluruhan, khususnya dalam mengatur sistem irigasi berupa pengelolaan air. Kelembagaan subak ini juga dibangun dibawah nilai nilai adat dan tradisi masyarakat. Namun dikarenakan keberagaman etnis penduduk di Kecamatan Bonegunu membuat kelembagaan adat ini memiliki perbedaan dengan sistem subak khususnya pada nilai nilai dan tradisi yang dijalankan.

Kelembagaan adat di kecamatan Bonegunu tidak memiliki agama maupun adat yang dominan dibandingkan dengan yang lainnya. Karakteristik masyarakat pun tidak ada yang mendominasi khususnya diantara para warga transmigran, selain itu masyarakat asli kecamatan Bonegunu didominasi oleh umat muslim dan secara adat dan tradisi tidak terlalu menyentuh pada sektor pertanian padi sawah, karena masyarakat asli kecamatan Bonegunu justru lebih banyak yang bekerja di kebun dibandingkan di sawah. Terkait dengan komposisi penduduk yang beragam, maka modal sosial yang dibangun diantara penduduk bukan didominasi oleh nilai-nilai adat maupun agama tertentu, tetapi nilai-nilai yang disepakati bersama oleh masyarakat. Norma - norma tersebut berjalan dengan baik dikarenakan adanya trust diantara masyarakat untuk saling menjaga norma-norma yang disepakati. Namun menariknya norma-norma yang disepakati berangkat dari norma-norma adat masing masing yang memiliki persamaan tujuan. Sehingga walaupun dapat dikatakan norma-norma universal, norma-norma universal ini lahir dengan warna norma-norma etnisitas. Normanorma universal ini hadir karena adanya konsensus antar kelompok etnik, sehingga walaupun masyarakat telah tersentuh normanorma universal, norma-norma etnisitas tetap eksis bertahan dan menguatkan eksistensi kelompok kelompok etnis. Sehingga modal sosial yang terjadi tidak hanya modal sosial diantara mereka dengan etnis yang sama tetapi juga antar etnis.

Selain kelembagaan adat/agama, terdapat pula Kelembagaan Ekonomi di Kecamatan Bonegunu. Adapun pada masing-masing desa memiliki kelembagaan yang berbeda-beda. Beberapa 
kelembagaan ekonomi lokal di kecamatan Bonegunu diantaranya adalah kelompok tani, Koperasi Unit Desa (KUD), usaha ekonomi produktif (UEP), dan lembaga ekonomi perempuan (LEP). Pada umumnya kelompok tani di desa berperan untuk mengurus terkait pertanian seperti jadwal tanam maupun ketersediaan benih dan pupuk, tetapi di beberapa desa kelompok tani juga berperan pada kegiatan simpan pinjam.

\section{Kondisi Ekonomi Masyarakat Pedesaan di Kecamatan Bonegunu Kabupaten Buton Utara}

Kecamatan Bonegunu secara umum memiliki potensi sawah yang tinggi. Namun potensi ini belum termanfaatkan dengan baik. Mengacu pada data statistik Kecamatan Bonegunu dalam Angka 2016 menyebutkan bahwa 36\% dari total lahan sawah di Kecamatan Bonegunu belum diusahakan. Hal ini dikarenakan kurangnya tenaga kerja untuk menggarap sawah tersebut. Masih cukup banyak lahan sawah yang belum termanfaatkan dikarenakan kurangnya tenaga kerja yang bersedia bekerja dibidang pertanian padi sawah. Kurangnya tenaga kerja ini diakibatkan karena belum signifikannya pendapatan dari hasil padi sawah dibandingkan hasil bumi lainnya sehingga masyarakat khususnya para penduduk asli belum mau secara optimal mengelola sawah mereka. Sejauh ini mereka yang menjadi petani padi sawah didominasi oleh etnis Bali dan Jawa yang merupakan transmigran yang melakukan transmigrasi ke Kabupaten Buton Utara pada Tahun 1993.

Pendapatan petani padi sawah belum signifikan dikarenakan panen yang mereka lakukan hanya sebanyak satu kali dalam setahun masa panen. Kondisi ini terjadi dikarenakan sawah mereka masih merupakan sawah tadah hujan. Maka dari itu ketersediaan air sangat mempengaruhi pengelolaan sawah tersebut. Walaupun pemerintah telah membantu membangun embung dan parit-parit untuk membantu pengairan sawah, ternyata hal ini juga belum cukup untuk memenuhi kebutuhan air sehingga perlu adanya pembangunan irigasi yang baik agar dapat meningkatkan produktivitas padi sehingga dapat berdampak pada tingginya pendapatan petani.
Kondisi ekonomi petani yang belum dapat dikatakan baik ini salah satunya disebabkan karena belum tersedianya saluran irigasi yang memadai. Maka dari itu untuk mengantisipasi dan sebagai bentuk adaptasi masyarakat, masyarakat memanfaatkan modal sosial dan hubungan kekerabatan yang terjalin diantara mereka sebagai upaya peningkatan kesejahteraan mereka. Hal ini menyebabkan kelembagaan ekonomi seperti koperasi simpan-pinjam atau kelompok tani sangat membantu perekonomian masyarakat. Masyarakat dapat meminjam kebutuhan seharihari dan mengembalikan saat panen tiba.

\section{Peran Kelembagaan Lokal (Etnistitas) dalam Meningkatkan Ekonomi Masyarakat Pedesaan di Kecamatan Bonegunu Kabupaten Buton Utara}

Kondisi ekonomi masyarakat kecamatan Bonegunu sangat terbantu dengan adanya kelembagaan lokal yang berkembang di daerah mereka. Salah satu contoh kasus adalah kelompok tani di Desa Gunung Sari. Kelompok tani di Desa Gunung Sari kini telah memiliki anggota kelompok sebanyak 30 orang. Seperti yang dipaparkan sebelumnya, kelompok tani biasanya berperan dalam penentuan jadwal tanam maupun ketersediaan benih dan pupuk, namun kelompok tani di Desa Gunung Sari juga berperan sebagai kelompok simpan pinjam untuk membantu perekonomian masyarakat.

Mekanisme simpan pinjam yang diterapkan cukup sederhana, yaitu masyarakat yang boleh meminjam adalah mereka yang telah terdaftar sebagai anggota kelompok dengan membayar uang pangkal kurang lebih sebesar Rp 10.000. Mereka boleh meminjam dan mengembalikan uang kelompok saat panen tiba. Selain itu kelompok tani juga mengusahakan penggilingan padi bersama sehingga keuntungannya dapat disisihkan untuk lembaga. Kelompok tani ini kini telah memiliki aset diatas Rp 10.000.000. Sejauh ini mekanisme peminjaman dan pengembalian selalu berjalan lancar. Kalaupun ada pengembalian yang bermasalah tidak lama akan dapat diselesaikan melalui pendekatan kekerabatan. Jika yang bermasalah dari etnis bali maka para petinggi adat bali akan membantu untuk menyelesaikannya, begitu juga sebaliknya. 
Proses peminjaman uang di kelompok tani ini tidak ada batasan nominal peminjaman dan syarat penggunaan pinjaman. Sistem pengembalian uang (baik cicilan maupun keseluruhan) dilakukan setiap enam bulan mengikuti musim panen, sehingga saat pembayaran uang pinjaman para petani sudah melewati masa panen dan memiliki uang untuk mengembalikan pinjaman tersebut. Adapun setiap bulannya para peminjam hanya diwajibkan untuk membayar cicilan bunga saja. Jika ada anggota yang tidak dapat membayar bunga selama tiga bulan berturut turut maka akan dikenakan denda tidak boleh meminjam lagi pada putaran selanjutnya, namun hal ini jarang terjadi karena di Kecamatan Bonegunu masyarakat desa masih memiliki modal sosial yang kuat sehingga jika ada anggota yang kesulitan membayar bunga biasanya akan dibantu oleh tetangganya untuk membayar bunga yang menjadi kewajibannya.

Selain kelompok tani, adapula KUD dan UEP. Kedua lembaga ekonomi ini memiliki tujuan untuk memberikan penguatan modal kepada petani dalam bentuk peminjaman modal. Sistem peminjaman dan pengembalian modal menerapkan sistem umum yang biasa dilakukan yaitu para peminjam meminjam modal kemudian dikembalikan secara mencicil setiap bulan berikut bunganya. Adapun lembaga ekonomi LEP memiliki sistem yang sama perbedaannya hanyalah anggota yang termasuk lembaga ini adalah perempuan. Tidak semua lembaga ekonomi disetiap desa tumbuh dan berkembang dengan baik. Pada umumnya lembaga ekonomi yang bertahan dan berkembang adalah lembaga ekonomi yang memiliki modal sosial yang kuat. Kelembagaan ekonomi di Kecamatan Bonegunu ternyata mampu berjalan dengan baik tanpa adanya peraturan yang kompleks. Kuatnya modal sosial diantara masyarakat mampu membuat kelembagaan ekonomi ini berjalan dengan baik dan efektif sebagai jaringan pengaman ekonomi pertama pada masyarakat di Kecamatan Bonegunu.

\section{SIMPULAN DAN SARAN}

\section{Simpulan}

Kelembagaan lokal yang berkembang di Kecamatan Bonegunu yaitu Kelembagaan adat. Kelembagaan ini didasari pada nilai-nilai adat maupun agama tertentu namun dalam tradisinya telah mengalami beberapa penyesuaian. Normanorma yang mewarnai kelembagaan ini yaitu norma-norma universal yang lahir dengan warna norma-norma etnisitas. Norma-norma universal ini hadir karena adanya konsensus antar kelompok etnik, sehingga walaupun masyarakat telah tersentuh norma-norma universal, normanorma etnisitas tetap eksis bertahan dan menguatkan eksistensi kelompok kelompok etnis. Sehingga modal sosial yang terjadi tidak hanya modal sosial diantara mereka dengan etnis yang sama tetapi juga antar etnis. Selain itu terdapat pula Kelembagaan Ekonomi di Kecamatan Bonegunu. seperti kelompok tani, Koperasi Unit Desa (KUD), usaha ekonomi produktif (UEP), dan lembaga ekonomi perempuan (LEP).

Kecamatan Bonegunu secara umum memiliki potensi sawah yang tinggi. Namun potensi ini belum termanfaatkan dengan baik dikarenakan belum tersedianya saluran irigasi yang memadai. Maka dari itu masyarakat memanfaatkan modal sosial dan hubungan kekerabatan yang terjalin diantara mereka. Sehingga koperasi simpanpinjam atau kelompok tani sangat membantu perekonomian masyarakat. Masyarakat dapat meminjam kebutuhan sehari-hari dan mengembalikan saat panen tiba. Maka dari itu peran kelembagaan lokal sangat penting dalam membantu perekonomian masyarakat, khususnya masyarakat petani. Selain itu adanya konsensus yang dibangun antar kelompok etnis juga membuat masyarakat multietnis dapat bersama sama mengatasi masalah ekonomi tanpa harus kehilangan identitasnya.

\section{Saran}

Lembaga ekonomi lokal yang berkembang pada masyarakat di Kecamatan Bonegunu Kabupaten Buton Utara merupakan lembaga yang memiliki peran sebagai penopang masyarakat dari segi ekonomi. Maka dari itu terdapat saran yang ditujukan bagi akademisi dan pemerintah agar kelembagaan ini dapat terus memberikan manfaat bagi masyarakat.

Bagi akademisi, perlu adanya penelitian lebih lanjut yang mengukur sejauh mana peran kelembagaan berjalan dengan efektif dan efisien agar dapat menemukan pola efektifitas 
kelembagaan agar dapat dipelajari dan diimplementasi pola kelembagaan lokal tersebut di daerah lain. Bagi pemerintah, perlu adanya perhatian dan pengakuan dari pemerintah terkait dengan eksistensi kelembagaan lokal tersebut agar dapat disinergikan dengan program pemerintah khususnya pada pemanfaatan potensi padi sawah di kecamatan Bonegunu.

\section{DAFTAR PUSTAKA}

[BPS] Badan Pusat Statistik Kabupaten Buton Utara. 2016. Kecamatan Bonegunu dalam Angka tahun 2016. Buton Utara: Badan Pusat Statistik Kabupaten Buton Utara

Barth, Fredrik. 1988. Kelompok Etnik dan Batasannya. Jakarta: UI Press.

Fredrickson, George M. 2003. Rasisme: Sejarah Singkat. Yogyakarta: PT. Bentang Pustaka.

Hermasyah, Aswandi, dan Herlina. 2008. Konflik dan Kekerasan Etnis dalam Masyarakat Multikultural (Analisis Budaya Terhadap Bekerjanya Sistem Peradilan Negara). Pontianak: Jurnal Penelitian Universitas Tanjungpura Volume IX No.1.

Nasdian, FT. 2015. Kelembagaan Sosial dalam Buku Sosiologi Umum. Jakarta: Yayasan Obor Indonesia. 
Barlan / Jurnal Sains Komunikasi dan Pengembangan Masyarakat 2(2): 147-154 